\title{
Wysokowydajne zgrzewanie FSW stopu aluminium przerabianego plastycznie
}

\author{
High speed FSW welding of wrought aluminium alloy
}

\section{Streszczenie}

Proces zgrzewania FSW jest stosunkowo prosty do realizacji w przypadku łączenia elementów wykonanych z takich samych materiałów lub materiałów nieznacznie różniących się własnościami fizycznymi. Zasadniczo, do tego rodzaju konstrukcji wykorzystuje się niewielkie prędkości zgrzewania. W artykule przedstawiono wyniki badań dotyczące wysokowydajnego zgrzewania metodą FSW stopu aluminium przerabianego plastycznie. Uzyskane rezultaty wskazują, że otrzymane połączenia cechują się wysoką jakością i pozbawione są wad oraz niezgodności.

Słowa kluczowe: zgrzewanie tarciowe z mieszaniem materiału zgrzeiny (FSW); stopy aluminium przerabiane plastycznie

\begin{abstract}
FSW process is relatively simple for realization in case of welding of similar materials or materials which slightly differ in their physical properties. Principally, for these types of application, low welding speeds are used. The article presents research results connected with high speed FSW welding of wrought aluminium alloy. Obtained results show that welds are characterized by high quality without any defects or imperfections.
\end{abstract}

Keywords: Friction Stir Welding; wrought aluminium alloys

\section{Wstęp}

Zastosowanie stopów aluminium ciągle wzrasta, a w związku z tym coraz częściej poszukuje się nowoczesnych metod ich łączenia oraz naprawy uszkodzonych elementów. Jedną $\mathrm{z}$ takich metod jest metoda zgrzewania tarciowego z mieszaniem materiału zgrzeiny (ang. Friction Stir Welding). Wykorzystanie metody FSW do zgrzewania stopów aluminium przerabianych plastycznie pozwala uniknąć typowych niezgodności spawalniczych, a dla niektórych materiałów staje się jedyną metodą ich łączenia w związku z trudnościami ze spawaniem [1].

Dotychczasowe wyniki badań naukowych dotyczących zgrzewania metodą FSW wskazują, że istotny wpływ na prawidłowe formowanie się zgrzeiny FSW oraz własności mechaniczne połączenia, wywiera rodzaj narzędzia zgrzewającego w tym jego kształt oraz wymiary [2]. Dodatkowo, na jakość powstałych zgrzein wpływają parametry procesu takie jak prędkość obrotowa narzędzia oraz prędkość zgrzewania. Prędkość obrotowa narzędzia wpływa na wymieszanie się materiałów wokół trzpienia. Im jest ona wyższa, tym bardziej wymieszany jest materiał w centralnym obszarze zgrzeiny i mniejsza jest wielkość ziarna oraz ilość generowanego ciepła [3]. Prędkość zgrzewania decyduje o wydajności procesu, dobierana jest w zależności od rodzaju materiału oraz wymagań konstrukcyjnych połączenia.

Biorąc pod uwagę stosowane, maksymalne prędkości zgrzewania dla poszczególnych materiałów należy zaznaczyć, że wartości prędkości zgrzewania wyższe aniżeli $800 \mathrm{~mm} / \mathrm{min}$ można już zaliczyć do wysokowydajnego zgrzewania metodą FSW. Biorąc pod uwagę obiecujące możliwości stosowania technologii FSW w warunkach produkcyjnych, istotnym staje się opracowanie technologii zgrzewania nie tylko pod kątem utworzenia połączenia o odpowiednich własnościach użytkowych, ale także $z$ uwagi na odpowiednio szybkie wykonywanie złączy.

\section{Materiały do badań, stanowisko i metodyka badawcza}

Badania technologiczne zgrzewania metodą FSW złączy doczołowych prowadzono z zastosowaniem blach o grubości $6 \mathrm{~mm}$ ze stopu aluminium przerabianego plastycznie AW-6082. Stop ten charakteryzuje wysoka wytrzymałość

Mgr inż. Damian Miara, dr inż. Jolanta Matusiak - Instytut Spawalnictwa, Gliwice.

Autor korespondencyjny/Corresponding author: damian.miara@is.gliwice.pl 
Tablica I. Skład chemiczny stopu aluminium EN AW-6082 wykorzystanego w badaniach [4]

Table I. Chemical compositon of EN AW-6082 aluminium alloy used during studies [4]

\begin{tabular}{|c|c|c|c|c|c|}
\hline \multirow{2}{*}{ Oznaczenie } & \multicolumn{5}{|c|}{ Zawartość pierwiastków } \\
\cline { 2 - 6 } & $\mathrm{Si}$ & $\mathrm{Cu}$ & $\mathrm{Mg}$ & $\mathrm{Mn}$ & $\mathrm{Fe}$ \\
\hline \multirow{3}{*}{$\begin{array}{c}\text { EN AW-6082 } \\
\text { (PA4) }\end{array}$} & $0,7 \div 1,3$ & $\leq 0,1$ & $0,6 \div 1,2$ & $0,4 \div 1,0$ & $\leq 0,5$ \\
\cline { 2 - 6 } & $\mathrm{Ti}$ & $\mathrm{Cr}$ & Zn & \multicolumn{2}{|c|}{ Al } \\
\cline { 2 - 6 } & $\leq 0,1$ & $\leq 0,2$ & $\leq 0,2$ & \multicolumn{2}{|c|}{ reszta } \\
\hline
\end{tabular}

Tablica II. Wybrane właściwości mechaniczne stopu aluminium EN AW-6082 [4]

Table II. Selected properties of aluminium alloy EN AW-6082[4]

\begin{tabular}{|c|c|c|c|}
\hline \multirow{2}{*}{ Oznaczenie } & \multicolumn{3}{|c|}{ Minimalne własności } \\
\cline { 2 - 4 } & $\begin{array}{c}\mathbf{R}_{\mathbf{p 0 , 2},} \\
\mathbf{M P a}\end{array}$ & $\begin{array}{c}\mathbf{R}_{\mathbf{m}}, \\
\mathbf{M P a}\end{array}$ & $\begin{array}{c}\mathbf{A}_{50}, \\
\%\end{array}$ \\
\hline $\begin{array}{c}\text { EN AW-6082 } \\
\text { (PA4) }\end{array}$ & 255 & 300 & 9 \\
\hline
\end{tabular}

mechaniczna oraz udarność, średnia wytrzymałość zmęczeniowa, daje się obrabiać skrawaniem. Posiada także dobrą odporność na korozję oraz podatność do polerowania. Szeroko wykorzystywany jest w przemyśle maszynowym, gdzie wymagania wytrzymałościowe są wyższe niż dla stopów serii 5000 . Stosowany jest na elementy nośne ciężarówek, autobusów, przyczep, statków, dźwigów, wagonów kolejowych, mostów, barier zabezpieczających.

Do badań wykorzystano jeden rodzaj narzędzia stożkowego, nagwintowanego typu Triflute (rys. 1). Badania nad technologią zgrzewania FSW stopów aluminium EN AW-6082 prowadzono $z$ prędkością obrotową narzędzia $V_{n}=1120$, 1400 i 1800 obr/min w zestawieniu z dwiema prędkościami zgrzewania $V_{z}=900$ i $1120 \mathrm{~mm} / \mathrm{min}$. Podczas przebiegu procesu zgrzewania, powierzchnię tarcia wieńca opory nachylono pod kątem $1,5^{\circ}$ do powierzchni zgrzewanych płyt.

Proces zgrzewania prowadzono na zgrzewarce FSW zbudowanej na bazie frezarki konwencjonalnej typu FYF32JU2, produkcji JAFO S.A. (rys. 2), wyposażonej w dodatkowe uchwyty mocujące zgrzewane elementy.

Pomiarów siły niszczącej złącza Fm [kN] dokonano na maszynie wytrzymałościowej typu INSTRON 4210 w oparciu o normę PN-EN ISO 4136:2013-05 [5]. W celu określenia wpływu parametrów procesu FSW na sposób wymieszania materiału, na przekrojach poprzecznych złączy przeprowadzono badania metalograficzne makroskopowe wybranych zgrzein zgodnie z normą 17639:2013-12 [6]. Badania twardości przeprowadzono na twardościomierzu KB-50BYZ-FA metodą Vickersa, zgodnie z normą PN-EN ISO 14271:2011 [7]. Obciążenie zadane wynosiło $1 \mathrm{~kg}$. Pomiarów twardości dokonywano w materiale podstawowym, w obszarze jądra zgrzeiny, w strefie odkształconej termomechanicznie oraz w strefie wpływu ciepła złącza na dwóch liniach pomiarowych.
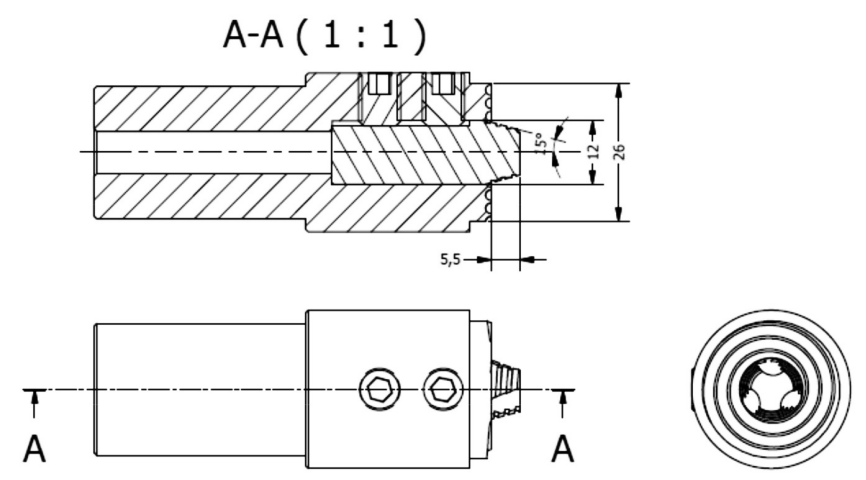

Rys. 1. Kształt i wymiary narzędzia wykorzystanego w badaniach Fig. 1. Shape and dimensions of tool used during studies
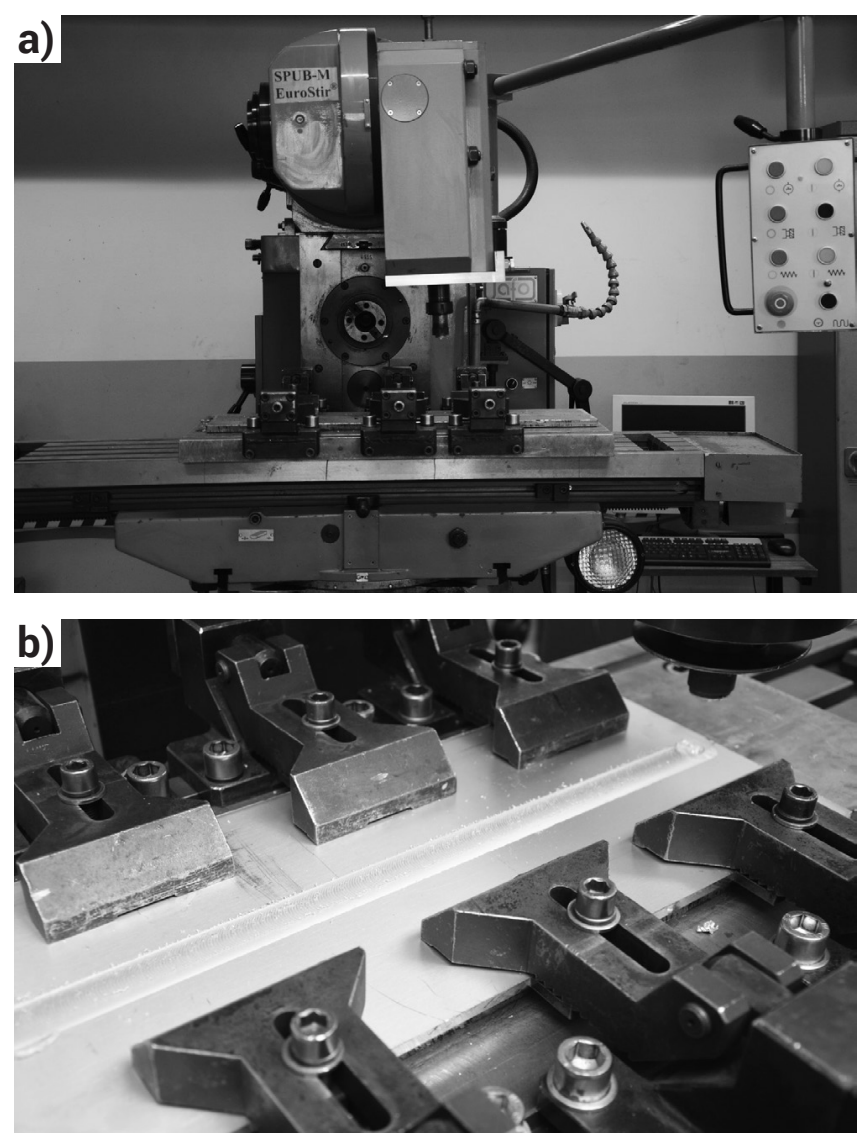

Rys. 2. Stanowisko zgrzewalnicze FSW wykorzystane w badaniach: a) frezarka konwencjonalna FYF32JU2, b) oprzyrządowanie zgrzewarki: uchwyty mocujące zgrzewane elementy

Fig. 2. The test stand for Friction Stir Welding: a) conventional vertical milling machine FYF32JU2, b) instrumentation: device for forces

\section{Wyniki badań}

\section{Badania wizualne}

Przeprowadzone wstępne badania, dotyczące możliwości wykonywania zgrzein z prędkościami zgrzewania wyższymi od $800 \mathrm{~mm} / \mathrm{min}$ za pomocą wybranego do zgrzewania narzędzia FSW, wskazują, że jest możliwe wykonywanie tego typu połączeń w całym badanym zakresie parametrów procesu zgrzewania. Powstałe zgrzeiny, zarówno od strony lica, jak i od strony grani, cechowały się kształtem charakterystycznym dla metody FSW. Po stronie lica dostrzegalne były charakterystyczne półokręgi, a zgrzeiny miały regularny kształt z niewielką ilością materiału na zewnątrz zgrzeiny, który w większości przypadków wychodził poza obszar 
zgrzewania od strony spływu. Na rysunkach $3 \div 5$ przedstawiono widok przykładowych zgrzein od strony lica.

Poprawnie dobrane parametry procesu zgrzewania umożliwiły wykonanie zgrzein trwałych, nastąpiła poprawna penetracja narzędzia w materiale rodzimym. W obszarze zgrzeiny po ustabilizowaniu procesu zgrzewania nie dostrzeżono występowania jakichkolwiek niezgodności. Świadczy to także o prawidłowo dobranym narzędziu do zgrzewania o odpowiednim kształcie i wymiarach.

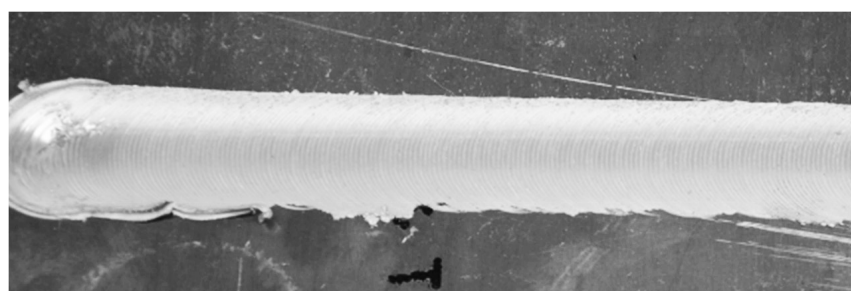

Rys. 3. Widok zgrzeiny doczołowej FSW ze stopu aluminium EN AW-6082 od strony lica. Parametry zgrzewania: $V_{n}=1120 \mathrm{obr} / \mathrm{min}$, $\mathrm{V}_{\mathrm{z}}=1120 \mathrm{~mm} / \mathrm{min}$

Fig. 3. View of the surfaces of the welds of EN AW-6082 aluminium alloys from the face of the weld. Welding parameters: $V_{n}=1120 \mathrm{rev} / \mathrm{min}$, $\mathrm{V}_{\mathrm{z}}=1120 \mathrm{~mm} / \mathrm{min}$

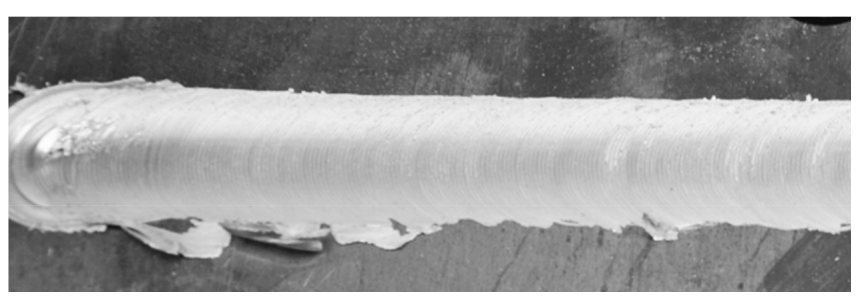

Rys. 4. Widok zgrzeiny doczołowej FSW ze stopu aluminium EN AW-6082 od strony lica. Parametry zgrzewania: $V_{n}=1400 \mathrm{obr} / \mathrm{min}$, $\mathrm{V}_{\mathrm{z}}=1120 \mathrm{~mm} / \mathrm{min}$

Fig. 4. View of the surfaces of the welds of EN AW- 6082 aluminium alloys from the face of the weld. Welding parameters: $V_{n}=1400 \mathrm{rev} / \mathrm{min}$, $\mathrm{V}_{\mathrm{z}}=1120 \mathrm{~mm} / \mathrm{min}$

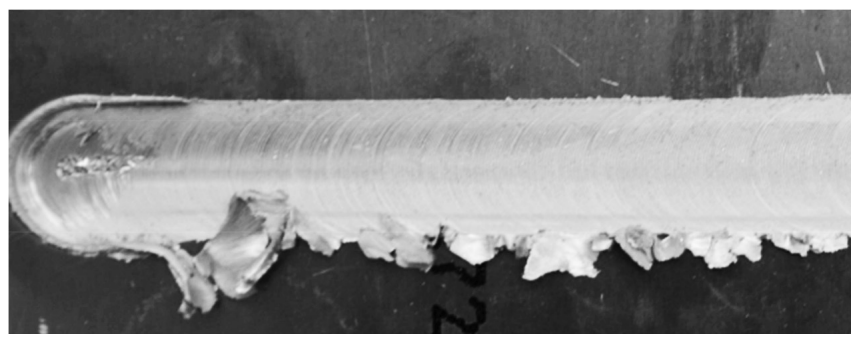

Rys. 5. Widok zgrzeiny doczołowej FSW ze stopu aluminium EN AW-6082 od strony lica. Parametry zgrzewania: $V_{n}=1800 \mathrm{obr} / \mathrm{min}$, $\mathrm{V}_{\mathrm{z}}=1120 \mathrm{~mm} / \mathrm{min}$

Fig. 5. View of the surfaces of the welds of EN AW-6082 aluminium alloys from the face of the weld. Welding parameters: $V_{n}=1800 \mathrm{rev} / \mathrm{min}$, $\mathrm{V}_{\mathrm{z}}=1120 \mathrm{~mm} / \mathrm{min}$

W zależności od zastosowanej prędkości obrotowej oraz prędkości zgrzewania, widok zewnętrzny zgrzein różni się jedynie $w$ niewielkim stopniu pomiędzy sobą - zgrzeiny przyjmują regularne kształty. Wraz ze wzrostem prędkości zgrzewania obserwuje się jedynie zwiększenie odległości pomiędzy kolejnymi „półokręgami” (śladami po postępie narzędzia).

\section{Badania wytrzymałości zgrzein na rozciąganie}

Jakość uzyskanych złączy, zgrzewanych metodą FSW przy różnych parametrach zgrzewania, została oceniona na podstawie wyników statycznej próby rozciągania. Widok przykładowej próbki FSW po próbie rozciągania przedstawiono na rysunku 6.

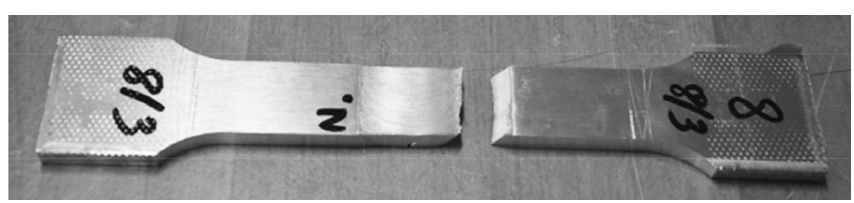

Rys. 6. Widok przykładowej próbki po próbie rozciągania. Parametry zgrzewania: $V_{n}=1800 \mathrm{obr} / \mathrm{min}, V_{z}=1120 \mathrm{~mm} / \mathrm{min}$

Fig. 6. Sample view after tensile test. Welding parameters:

$\mathrm{V}_{\mathrm{n}}=1800 \mathrm{rev} / \mathrm{min}, \mathrm{V}_{\mathrm{z}}=1120 \mathrm{~mm} / \mathrm{min}$

Aby zobrazować zmiany średnich wartości wytrzymałości zgrzein FSW na rozciąganie (na podstawie 5 próbek dla każdego połączenia) przedstawiono je w zależności od prędkości zgrzewania (rys. 7) dla trzech prędkości obrotowych narzędzia 1120, 1400 i 1800 obr/min, natomiast na rysunku 8 przedstawiono zależność średnich wartości wytrzymałości zgrzein FSW na rozciąganie od prędkości obrotowych narzędzia dla dwóch prędkości zgrzewania tj. 900 i 1120 mm/min.

Wyniki badań wytrzymałości na rozciąganie jednoznacznie wskazują, że niezależnie od zastosowanych parametrów procesu zgrzewania tj. zmieniając zarówno prędkość obrotową, jak i prędkość zgrzewania uzyskano praktycznie takie same wartości średniej wytrzymałości na rozciąganie. Różnice pomiędzy poszczególnymi próbkami są na tyle małe, że są niezauważalne na wykresach porównawczych. Można więc określić, że różnice te są pomijalne.

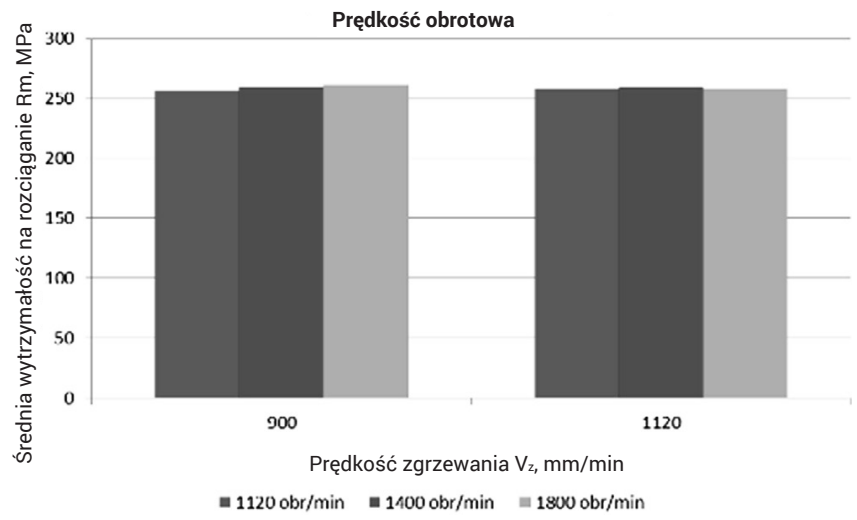

Rys. 7. Wykres zależności średniej wytrzymałości na rozciąganie $\mathrm{Rm}$ od prędkości zgrzewania dla trzech prędkości obrotowych narzędzia $V_{n}=1120,1400$ i $1800 \mathrm{obr} / \mathrm{min}$

Fig. 7. The plot of dependence between average tensile strength and welding speed for three tool rotational speeds $V_{n}=1120,1400$ i $1800 \mathrm{rev} / \mathrm{min}$

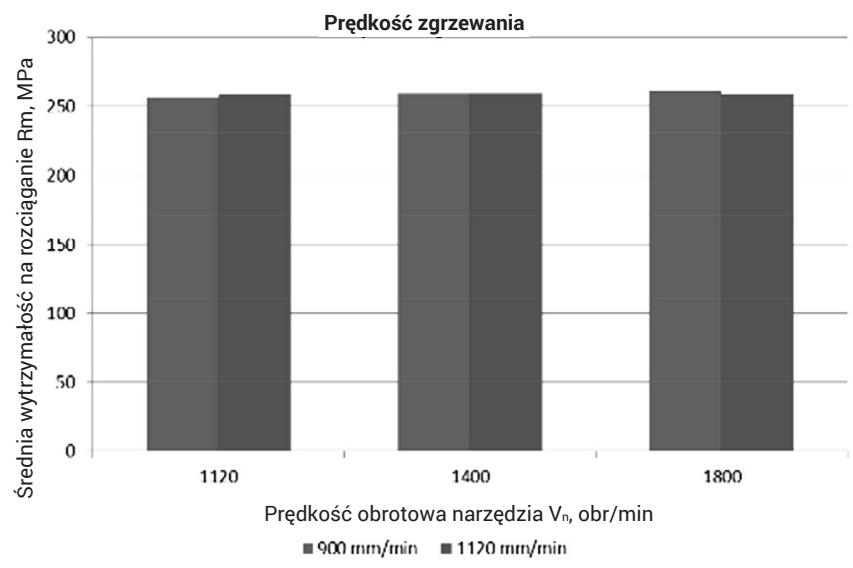

Rys. 8. Wykres zależności średniej wytrzymałości na rozciąganie $\mathrm{Rm}$ od prędkości obrotowej narzędzia dla dwóch prędkości zgrzewania $\mathrm{V}_{\mathrm{z}}=900$ i $1120 \mathrm{~mm} / \mathrm{min}$

Fig. 8. The plot of dependence between average tensile strength and welding speed for two tool welding speeds $\mathrm{V}_{\mathrm{z}}=900$ and $1120 \mathrm{rev} / \mathrm{min}$ 
Podobne wyniki osiągamy zarówno przy analizowaniu zależności średniej wytrzymałości na rozciąganie od prędkości obrotowej, jak i zależności średniej wytrzymałości na rozciąganie od prędkości zgrzewania. Z punktu widzenia technologii zgrzewania należy przeprowadzić dodatkowe badania, które wskażą czy uzyskane wyniki są już maksymalnymi do osiągnięcia dla tego typu technologii w odniesieniu do stopów aluminium EN AW-6082 zgrzewanych doczołowo.

\section{Badania metalograficzne makroskopowe}

Dla wybranych próbek przeprowadzono badania metalograficzne makroskopowe budowy strukturalnej zgrzein. Przygotowanie próbek do badań metalograficznych makroskopowych, polegało na wycięciu zgrzein ze złączy w taki sposób, aby możliwe było uzyskanie przekroju poprzecznego badanych zgrzein. Makrostruktury wybranych zgrzein przedstawiono na rysunkach 9 $\div 11$ (dla prędkości zgrzewania $1120 \mathrm{~mm} / \mathrm{min}$ ).

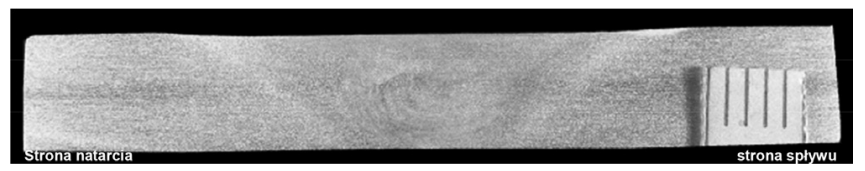

Rys. 9. Makrostruktura zgrzeiny FSW, wykonanej z blach ze stopu aluminium EN AW-6082. Parametry zgrzewania $V_{n}=1120 \mathrm{obr} / \mathrm{min}$, $V_{z}=1120 \mathrm{~mm} / \mathrm{min}$. Traw. Keller

Fig. 9. Macrostructure of FSW weld made from EN AW-2017A aluminium alloy. Welding parameters: $V_{n}=1120 \mathrm{rev} / \mathrm{min}, V_{z}=1120 \mathrm{~mm} / \mathrm{min}$. Etching Keller

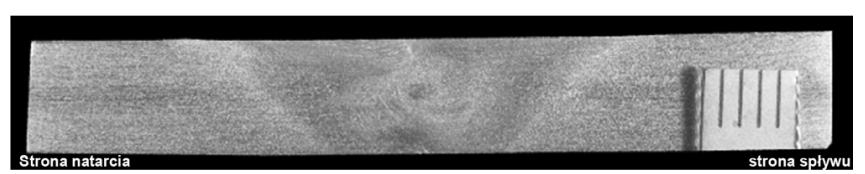

Rys. 10. Makrostruktura zgrzeiny FSW, wykonanej z blach ze stopu aluminium EN AW-6082. Parametry zgrzewania $V_{n}=1400 \mathrm{obr} / \mathrm{min}$, $\mathrm{V}_{\mathrm{z}}=1120 \mathrm{~mm} / \mathrm{min}$. Traw. Keller

Fig. 10. Macrostructure of FSW weld made from EN AW-2017A aluminium alloy. Welding parameters: $V_{n}=1400 \mathrm{rev} / \mathrm{min}, V_{z}=1120 \mathrm{~mm} /$ min. Etching Keller

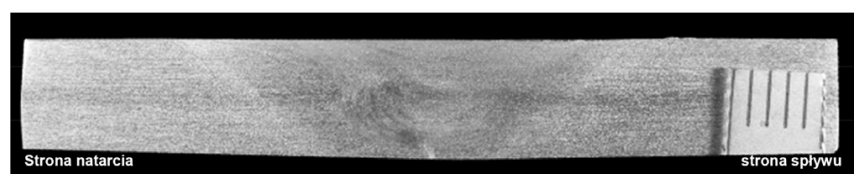

Rys. 11. Makrostruktura zgrzeiny FSW, wykonanej z blach ze stopu aluminium EN AW-6082. Parametry zgrzewania $V_{n}=1800 \mathrm{obr} / \mathrm{min}$, $V_{z}=1120 \mathrm{~mm} / \mathrm{min}$. Traw. Keller

Fig. 11. Macrostructure of FSW weld made from EN AW-2017A aluminium alloy. Welding parameters: $V_{n}=1800 \mathrm{rev} / \mathrm{min}, V_{z}=1120 \mathrm{~mm} /$ min. Etching Keller

Przedstawione na rysunkach przykładowe makrostruktury zgrzein, wykonane z połączenia blach ze stopu aluminium EN AW-6082 wskazują, że obszar połączenia cechuje się pełną ciągłością metaliczną. Dla każdej próbki wyraźnie dostrzegalna jest strefa odkształcona termomechanicznie wskutek oddziaływania wieńca opory, jądro zgrzeiny oraz strefy wpływu ciepła (zarówno po stronie natarcia, jak i stronie spływu). Zgrzeiny przyjmują kształt trapezu niezależnie od zastosowanej kombinacji parametrów procesu zgrzewania.

\section{Pomiary twardości}

Aby zobrazować zmiany twardości dla wybranych próbek FSW wykonanych ze stopu aluminium EN AW-6082, na rysunkach $12 \div 14$ przedstawiono wykresy twardości na przekrojach złączy.
Wyniki badań twardości przedstawione na rysunkach $12 \div 14$ wskazują na typowy przebieg zmian twardości dla złączy wykonanych metodą FSW. Następuje niewielki wzrost twardości w centralnych obszarach zgrzein i jej nieznaczne obniżenie w strefie wpływu ciepła zarówno po stronie natarcia jak i po stronie spływu. Zasadniczo, niezależnie od zastosowanych parametrów procesu zgrzewania, nie zmienia się ani charakter zmian twardości na przekrojach, ani wartości pomiarów twardości.
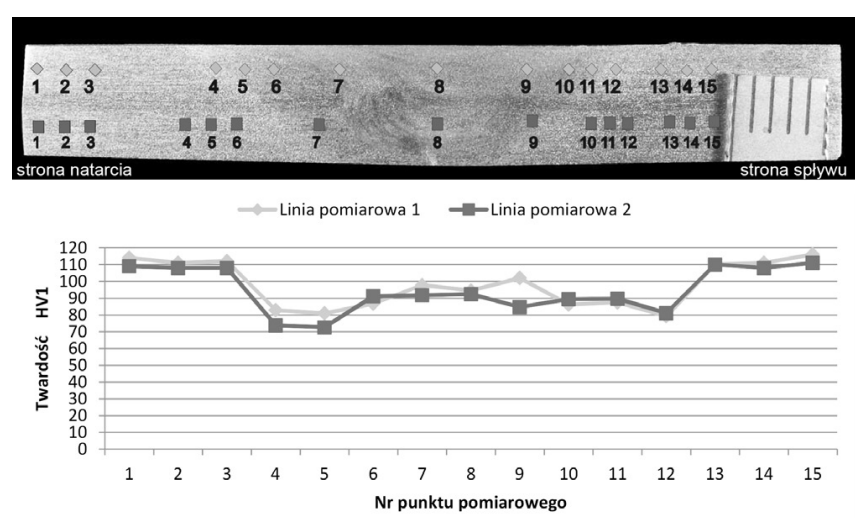

Rys. 12. Wartości twardości na przekroju złącza zgrzewanego FSW $z$ aluminium EN AW-6082. Parametry zgrzewania $V_{n}=1120 \mathrm{obr} / \mathrm{min}$, $\mathrm{V}_{\mathrm{z}}=1120 \mathrm{~mm} / \mathrm{min}$

Fig. 12. Hardness values on the cross section of the FSW weld of EN AW-6082 aluminium alloy. Welding parameters: $V_{n}=1120 \mathrm{rev} / \mathrm{min}$, $\mathrm{V}_{\mathrm{z}}=1120 \mathrm{~mm} / \mathrm{min}$

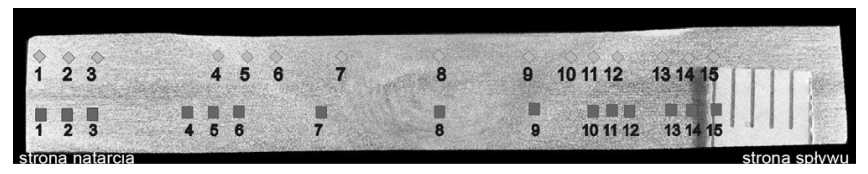

$\rightarrow$ Linia pomiarowa $1 \rightarrow$-Linia pomiarowa 2

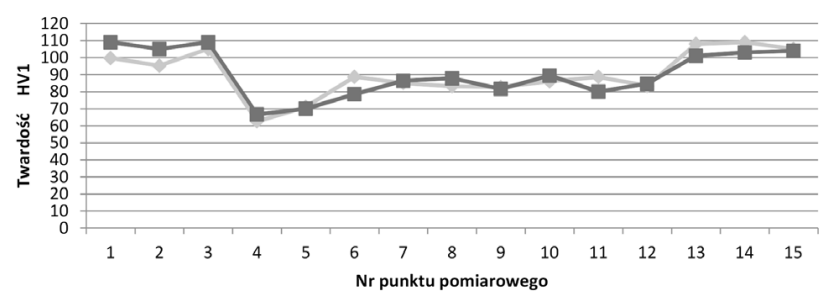

Rys. 13. Wartości twardości na przekroju złącza zgrzewanego FSW $z$ aluminium EN AW-6082. Parametry zgrzewania $V_{n}=1400 \mathrm{obr} / \mathrm{min}$, $\mathrm{V}_{\mathrm{z}}=1120 \mathrm{~mm} / \mathrm{min}$

Fig. 13. Hardness values on the cross section of the FSW weld of EN AW-6082 aluminium alloy. Welding parameters: $V_{n}=1400 \mathrm{rev} / \mathrm{min}$, $\mathrm{V}_{\mathrm{z}}=1120 \mathrm{~mm} / \mathrm{min}$
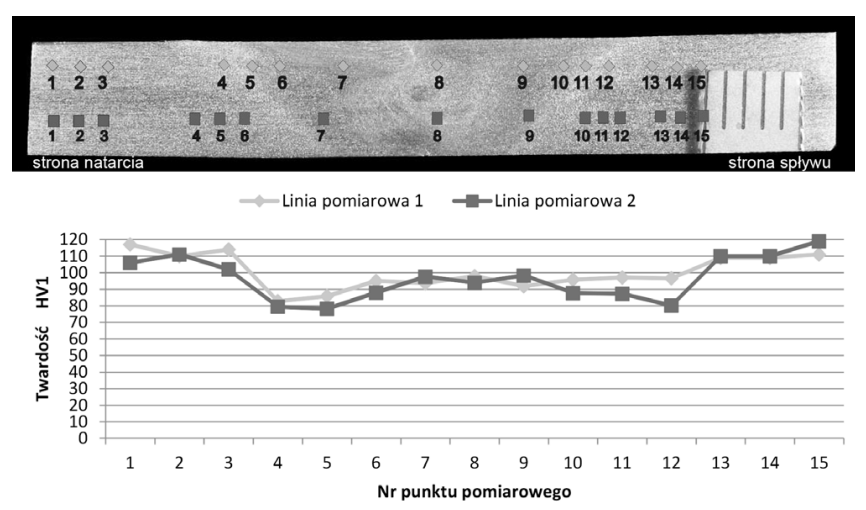

Rys. 14. Wartości twardości na przekroju złącza zgrzewanego FSW $z$ aluminium EN AW-6082. Parametry zgrzewania $V_{n}=1800 \mathrm{obr} / \mathrm{min}$, $\mathrm{V}_{\mathrm{z}}=1120 \mathrm{~mm} / \mathrm{min}$

Fig. 14. Hardness values on the cross section of the FSW weld of EN AW-6082 aluminium alloy. Welding parameters: $V_{n}=1800 \mathrm{rev} / \mathrm{min}$, $\mathrm{V}_{\mathrm{z}}=1120 \mathrm{~mm} / \mathrm{min}$ 


\section{Analiza wyników badań}

Jakość powstałych w procesie FSW złączy doczołowych ze stopu aluminium EN AW-6082 jest bardzo wysoka i powtarzalna. Badania wizualne wykazały, że niezależnie od zastosowanych parametrów procesu zgrzewania, tj. przy zgrzewaniu z trzema prędkościami obrotowymi (1120, 1400 i 1800 obr/min) oraz dwiema prędkościami zgrzewania (900 i $1120 \mathrm{~mm} / \mathrm{min}$ ) wizualnie jakość uzyskanych zgrzein jest bardzo podobna. Wcześniej prowadzone prace, na podobnych do stopu aluminium EN AW-6082 materiałach, wskazują, że wysoce prawdopodobne jest uzyskanie podobnych rezultatów w postaci zgrzein przy zastosowaniu również innych rodzajów narzędzi. Materiał EN AW-6082 jest dobrze zgrzewalny metodą FSW i wysoką jakość zgrzein można uzyskać w bardzo szerokim zakresie parametrów procesu zgrzewania.

Dla wszystkich badanych próbek, wykonanych przy zastosowaniu różnych zestawów parametrów procesu zgrzewania przeprowadzono badania wytrzymałości zgrzein na rozciąganie. Jak wykazały pomiary, średnia wytrzymałość na rozciąganie praktycznie nie zmienia się wraz ze zmianą jakichkolwiek parametrów procesu zgrzewania. Na ostateczną wartość wytrzymałości zgrzein na rozciąganie nie wpływa więc ani zmiana prędkości obrotowej narzędzia, ani zmiana prędkości zgrzewania. Najmniejsza wartość wytrzymałości, jaką uzyskano podczas badań, to $253 \mathrm{MPa}$ (przy $\mathrm{V}_{\mathrm{n}}=1800 \mathrm{obr} / \mathrm{min}$, $V_{z}=1120 \mathrm{~mm} / \mathrm{min}$ ), natomiast największa to $264 \mathrm{MPa}$ (przy $V_{n}=1400 \mathrm{obr} / \mathrm{min}, V_{z}=900 \mathrm{~mm} / \mathrm{min}$ ). Jednak $\mathrm{w}$ ogólnym, średnim zestawieniu wytrzymałość na rozciąganie waha się w przedziale $256 \div 261 \mathrm{MPa}$.
Badania metalograficzne makroskopowe wykazały, iż powstałe zgrzeiny cechują się pełną ciągłością metaliczną. Zgrzeiny nie wykazały śladów „braku zgrzania”, występowania wtrąceń czy innych niezgodności. Niezależnie od zastosowanych parametrów procesu zgrzewania, zgrzeina cechowała się podobną budową - wykazywała charakterystyczny, trapezoidalny kształt budowy zgrzeiny. Pełna ciągłość metaliczna powstałych zgrzein przełożyła się na ich wysokie wartości wytrzymałości na rozciąganie przy jednoczesnej powtarzalności uzyskiwanych wyników.

Analizując przeprowadzone wyniki badań wytrzymałości na rozciąganie oraz badań metalograficznych makroskopowych można stwierdzić, że potwierdzają one wysoką i powtarzalną jakość uzyskanych zgrzein, na którą wskazują także wyniki badań wizualnych. Jakość zgrzein nie zmienia się wraz ze zmianą zarówno prędkości obrotowych narzędzia, jak i prędkości zgrzewania.

Analogicznie jak w przypadku badań wytrzymałości zgrzein na rozciąganie, również wyniki pomiarów twardości nie wykazują większych zmian w zależności od tego, czy zmieniano podczas prowadzenia procesu zgrzewania prędkość obrotową narzędzia lub prędkość zgrzewania. Charakter przebiegu zmian twardości w każdym przypadku jest bardzo podobny. Można zaobserwować niewielki spadek twardości w obydwu strefach wpływu ciepła oraz niewielki wzrost w centralnym obszarze zgrzeiny. Charakter zmian twardości jest charakterystyczny dla metody FSW dla stopów aluminium przerobionych plastycznie.

\section{Wnioski}

- Zastosowanie narzędzia stożkowego typu Triflute, do wysokowydajnego zgrzewania FSW stopu aluminium EN AW-6082, umożliwia wykonywanie zgrzein o wysokiej jakości. Proces zgrzewania jest powtarzalny i można go prowadzić w szerokim zakresie parametrów procesu zgrzewania.

- Proces zgrzewania FSW prowadzony był z wykorzystaniem narzędzia o odpowiedniej długości trzpienia - powstałe zgrzeiny cechowały się pełną ciągłością metaliczną i pozbawione były niezgodności budowy strukturalnej w tym przede wszystkim niezgodności związanych z „brakiem zgrzania” od strony grani.

- Zmiana zarówno prędkości obrotowej narzędzia, jak i prędkości zgrzewania nie wpływa na wyniki badań w statycznej próbie rozciągania. Powstałe zgrzeiny cechowały się wysoką jakością. Średnie wartości wytrzymałości zgrzein na rozciąganie pozostawały na stałym poziomie i wahały się w przedziale $253 \div 264 \mathrm{MPa}$.

\section{Literatura}

[1] Bhadeshia H.K.D.H.: Friction Stir Welding, Cambridge, 2002.

[2] Elangovan K., Balasubramanian V., and Babu S.: Developing an Empirical Relationship to Predict Tensile Strength of Friction Stir Welded AA2219 Aluminum Alloy, Journal of Materials Engineering and Performance, No 820 , Vol. 17(6), 2008

[3] Rajiv S., Mishra A., Murray W., Mahoney E.: Friction stir welding and processing, ASM International, 2007.

[4] PN-EN 573-3:2014-02 Aluminium i stopy aluminium - Skład chemiczny i rodzaje wyrobów przerobionych plastycznie - Część 3: Skład chemiczny i rodzaje wyrobów.
[5] PN-EN ISO 4136:2013-05E Badania niszczące złączy spawanych metali - Próba rozciągania próbek poprzecznych.

[6] PN-EN ISO 17639:2013-12 Badania niszczące spawanych złączy metali - Badania makroskopowe i mikroskopowe złączy spawanych.

[7] PN-EN ISO 14271:2011 Zgrzewanie rezystancyjne - Badanie twardości metodą Vickersa (przy małym obciążeniu i mikrotwardości) zgrzein rezystancyjnych punktowych, garbowych i liniowych. 